\title{
Strategic Political Support for Term Limits
}

\author{
James Coleman Battista
}

I create a simple formal model of support for term limits which predicts that respondents in districts represented by the other party should more strongly favor term limits. An additional layer of theory predicts that weak Democrats and strong Republicans should be most responsive to the incentives illustrated in the formal model. Using the 1992, 1994, and 1998 National Election Studies, I find support for both of these hypotheses.

In recent years, term limits for members of Congress as well as state legislators has been a hot topic of discussion both in academia as well as in public discourse. Numerous theoretical pieces (for examples, see Grofman 1996) argue for varying positions on term limits. Much of this academic literature reflects more popular argument about the partisan effects of term limits as well as the effects of term limits on the behavior of legislators, such as Will (1992).

More recently, Carey, Niemi, and Powell (2000) provided empirical evidence about what effects limiting legislative terms has had so far. They found that with the exception of increasing the number of women and a slight bias towards conservatism, term limits have had no visible effect on the composition of legislatures. On the other hand, they find that termlimited legislators spend less time campaigning and fund-raising, keeping in touch with constituents, engaging in casework, and bringing home projects to the district than do their non-term-limited counterparts.

In contrast to the large academic and popular literatures on term legislative term limits, there has been relatively little work on why they command such strong support among the mass public. National, regional, or city surveys consistently find support for term limits (either on Congress or state legislatures) running in the range of 75-80 percent. Current models find that term limits are more heavily favored by some underrepresented groups (depending strongly on the study), by people dissatisfied with their representative or with the relevant legislature, and by people with less social trust. A very recent model (Stein, Johnson, and Post 2002) provides initial evidence that being in the local out-party may be a factor as well.

I further explore the out-party notion in the congressional setting. To provide some micro-foundations, I offer a simple formal model illustrating

JAMES COLEMAN BATTISTA is an assistant professor of political science at the University of North Texas.

The American Review of Politics, Vol. 25, Summer, 2004: 119-136

(C)2004 The American Review of Politics 
the short- and long-term tradeoffs inherent in term limits and showing that out-partisans should essentially always view term limits more favorably than do in-partisans. I also apply an additional layer of theory to gain some leverage over the question of who should be less and more responsive to this effect. Testing in the 1992, 1994, and 1998 National Election Studies, I find strong support for the hypotheses that out-partisans should be stronger supporters of term limits for Congress in the pattern predicted by the second layer of theory.

\section{Explanations of Support for Term Limits}

At present, the various models of mass support for term limits test six classes of variables:

1. Self-interest/representational-Respondents should be more likely to support term limits if they are a member of a group or party that is predicted to gain representation under term limits. Theoretical and empirical work indicates that these gaining groups are likely to include women, Blacks and Hispanics, and Republicans as the currently over-represented Anglos, men, and Democrats lose their incumbency advantage (Thompson and Moncrief 1993; Moncrief, Thompson, and Hoyer 1996). As noted previously, I do not find these effects with the possible exception of a shift towards greater representation of women in term-limited states. However, these effects may simply be slow enough to actually require sitting legislators to begin losing their seats to term limits en masse.

2. Dissatisfaction-Respondents should be more likely to favor term limits if they disapprove of their legislature or legislator. Obviously, if a respondent is dissatisfied with his or her legislator, instituting term limits would remove the offending legislator. Likewise, if a respondent is dissatisfied with the performance of a legislatures as a whole, as is more often the case, term limits would also force other districts to replace their (presumptively poorly-performing) legislators at the cost of also losing the respondent's better-liked legislator.

3. Cynicism-Respondents should be more likely to favor term limits if they are more cynical or less trusting. This may reflect a withdrawal of support from either the entire regime or merely the people actually engaged in governance (Karp 1995, 376).

4. Ideology-Respondents should be more likely to favor term limits if they are more conservative. This follows from arguments such as Will's that the intense effort for re-election found in Congress is behind the distribution of pork and other presumptively wasteful and/or undesirable programs. Further, Will argues that prolonged presence in the Washington establishment has a corrupting or at least desensitizing influence on members of Congress, 
leading to the wide-reaching welfare and regulatory state that conservatives tend to oppose (Will 1992, 34-50).

5. Campaign effects-Respondents should be more likely to favor term limits if they are currently on the ballot in a respondent's state, as this will help to bring the issue to the public eye and will provide a greater flow of information to the public. Likewise, contact from groups or parties should affect a person's propensity to favor term limits (Donovan and Snipp 1994, 494).

6. Partisan incongruity - Respondents should be more likely to favor term limits if they are represented by someone of the other main party (Stein, Johnson, and Post 2002). Stein, Johnson, and Post's logic is that Republicans in 1992 favored term limits for Congress in part because they believed it might gain them a majority in Congress, or at the district level an out-partisan might wish to see an incumbent from the other party be replaced (Stein, Johnson, and Post 2002, 462-463). I extend this logic, pointing out an essential tradeoff-while term limits might make it easier for an outpartisan to win a given seat, it also makes it harder for the new in-party to hold that seat for an extended period.

Five primary studies explain mass support for term limits, making use of these classes of variables. Boeckelman and Corell (1996) conduct an aggregate level study of county election returns on term limitation proposals in 16 states. Boeckelman and Corell find strong evidence that the partisanship of counties has a substantial effect on the county's vote in term limitation elections, with more Republican counties having greater support for term limits. This bolsters both the self-interest/representational and ideological hypotheses (Boeckelman and Corell 1996, 192-193). However, they find only an inconsistent relationship between a county's racial composition and its vote (Boeckelman and Corell 1996, 194).

Rausch and Copeland (1996) conduct an analysis of several polls, including a national Gallup poll and a television poll in Oklahoma. Providing only simple crosstabs, Rausch and Copeland suggest that support for term limits is nearly universal and that it cuts across many of the social cleavages that are usually important. However, they do argue that those citizens with higher SES and more education, as well as Democrats, are more likely to be in the small group opposing term limits (Rausch and Copeland 1996, 211).

Using data from a 1990 poll of California voters, Donovan and Snipp (1994) run a series of logistic regressions to test group and partisan representational hypotheses as well as campaign effects and ideology. They find that while women are more likely to favor term limits (at approximately a 0.10 significance level), there are no effects among Black and Hispanic voters. Donovan and Snipp also find that older people are more likely to support term limits, as are Republicans. However, they find no effect for conservatism. Finally, they find that those contacted by Democrats are more 


\section{2 | James Coleman Battista}

likely to oppose term limits, while those contacted by Republicans were more likely to favor them (Donovan and Snipp 1994, 498).

Karp (1995) uses several surveys, including the 1992 National Election Study and polls in Florida (1991) and Wyoming (1992), to examine five hypotheses: self-interest, ideology, dissatisfaction, cynicism, and campaign effects. Karp finds only cynicism to have a consistent effect (Karp 1995, 382-384). In addition, Karp finds that party identification interacting with a political knowledge instrument has a significant effect in the NES, as does the presence of a term limits campaign facing serious opposition (Karp 1995, 382). Finally, Karp finds that women were more likely to support term limits in Florida (at a 0.06 level of significance) (Karp 1995, 383).

Finally, Stein, Johnson, and Post (2002) add a first look at in-partisan versus out-partisan status at the district level. Using an original survey in Houston as well as the 1994 American National Election Study, they find that a mismatch between the respondent's party and his or her state or federal representative's party has a mixed effect. In their 1998 Houston survey, they find that party incongruence leads to support for term limits for both state legislators and U.S. Representatives, at least among those with higher attentiveness. In the 1994 NES, they find a weaker relationship that is still significant at a 0.10 level.

This leaves us with little consistent evidence on determinants of support for term limits. The most consistent effect is that of cynicism, which is highly significant everywhere it is measured. Next is party, which is generally significant but not significant by itself in any of the polls Karp analyzes. The only group representational effect to show up at all is that of women, and that only in a few analyses.

\section{Theory 1: A Simple Model of Strategic Support}

However, this may not be the end of the story. As Stein, Johnson, and Post note, out-partisans (at the legislative or district level) may be more likely to favor term limits. Here, I will focus on the district level. That is, a Democrat in a Republican area should be more likely to support term limits than a Democrat in a Democratic area. A first-cut reason for this is simple enough: it would provide their party's candidate with a more easily won open-seat election, and do so at regular intervals.

However, this also reveals a cost - if term limits are enacted, it may be easier for a local out-party to take a congressional seat, but, should they win, they would not be able to obtain the electoral "lock" on the district that they might be able to without term limits. Consider a Republican district in the absence of term limits - should a Democrat be able to win that seat, he or she might well be able to remain in Congress (or the state legislature) until he or she chooses to retire. ${ }^{1}$ If term limits are enacted, the Democrats will 
have somewhat more regular "access" to the seat in the form of required open-seat elections. However, once won, that seat is now less valuable to the Democrats owing to its reduced life-expectancy.

To get at this tradeoff, I offer a simple formal model of this process. To bring the tradeoff into clearest light, the model compares a world with very large incumbency advantages to a world with very harsh term limits. First, assume a series of three elections. The probability of defeating an incumbent and taking the seat from the current in-party is $P_{i n c}$, which is presumably low. In a term-unlimited world, if the out-party takes the seat, they become the new in-party and can secure re-election with the same 1- $P_{\text {inc }}$ probability that the previous party did. Thus, without term limits, the current out-party has a low probability of winning the seat, but a high probability of retaining it if won.

In this simple model, I implement the harshest form of term limits possible: nobody may serve more than one term. This transforms every election into an open seat election, so in every election the current out-party can win or retain the seat with probability $P_{\text {open }}$, in all likelihood much higher than $P_{\text {inc. }}$.

Consider these two schemes from the point of view of a constituent in the current out-party. If the constituent's preferred candidate wins, he or she accrues some benefit (1), while if the candidate of the other party wins, the constituent receives some smaller amount that can be set to zero without loss of generality. A win now is more desirable than a win later, so later payoffs are discounted by $\delta$ such that $0 \leq \delta \leq 1$. From this, it is possible to construct the present expected utility of an electoral system to the constituent. This can be done for both unlimited and limited terms, with the results then compared.

\section{Unlimited Terms}

To find the present expected utility of an unlimited-term scheme for the current out-party constituent, we need merely delineate how the probabilities and discount factors play out over the three elections.

Figure 1 illustrates the possibilities for an out-party constituent. In the next election, his or her party has only a $P_{\text {inc }}$ chance of winning and obtaining benefits of 1 . Should they lose, they face the same odds in the next election. However, should Party 2 win the first election, they begin to accrue the incumbency advantage, giving them the better odds of 1-P inc in the next election. From this, it is possible to construct the net present expected utility of this system for an out-party constituent. In this case, this equals the cumbersome $U_{n t l}=P_{i n c}+2 P_{i n c} \delta-2\left(P_{i n c}\right)^{2} \delta+3 P_{i n c} \delta^{2}-6\left(P_{i n c}\right)^{2} \delta^{2}+4\left(P_{i n c}\right)^{3} \delta^{2}$. However, this value is only really important when compared to its term-limited counterpart. 
Figure 1. Value of Unlimited-Term Regime to Out-Partisan

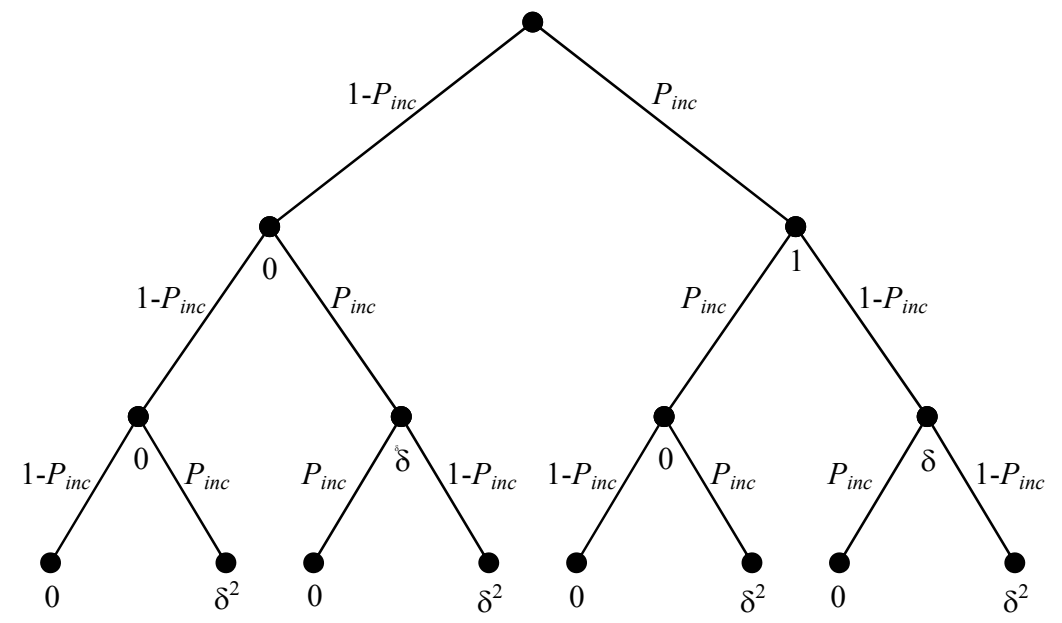

\section{Limited Terms}

Under the extremely harsh term limits here, the odds of obtaining a seat are the same as the odds of retaining it. Figure 2 displays the paths that may occur under this alternative. For a strict term limits regime, the present expected utility collapses to a much simpler $U_{t l}=P_{\text {open }}+\left(P_{\text {open }}\right)^{2}+\left(P_{\text {open }}\right)^{3}$.

\section{Differences}

Because they share no terms except $\delta$, the difference between unlimited and limited terms is simply $\left(P_{\text {open }}+\left(P_{\text {open }}\right)^{2}+\left(P_{\text {open }}\right)^{3}\right)-\left(P_{\text {inc }}+2 P_{\text {inc }} \delta-2\left(P_{\text {inc }}\right)^{2} \delta+\right.$ $\left.3 P_{\text {inc }} \delta^{2}-6\left(P_{\text {inc }}\right)^{2} \delta^{2}+4\left(P_{\text {inc }}\right)^{3} \delta^{2}\right)$. In plain language, all that this means is that a constituent weighs his or her perception of how hard it is to defeat incumbents against his or her perception of the party's odds in an open-seat election. The easiest way to make sense of this is graphically. Figure 3 displays the curves where $U_{t l}=U_{n t l}$ for several values of $\delta$. Because it would seem silly to enact term limits in a world where incumbents tend to lose (with a $P_{\text {inc }}>0.5$ ), I restrict the graph to probabilities less than one-half. In each case, the area below and to the right of the curve are the mixes of $P_{\text {inc }}$ and $P_{\text {open }}$ such that the constituent favors the current, unlimited-term regime, and the region above and to the left of the curve indicates that the constituent is better off with term limits. 
Figure 2. Value of Term-Limited Regime to Out-Partisan

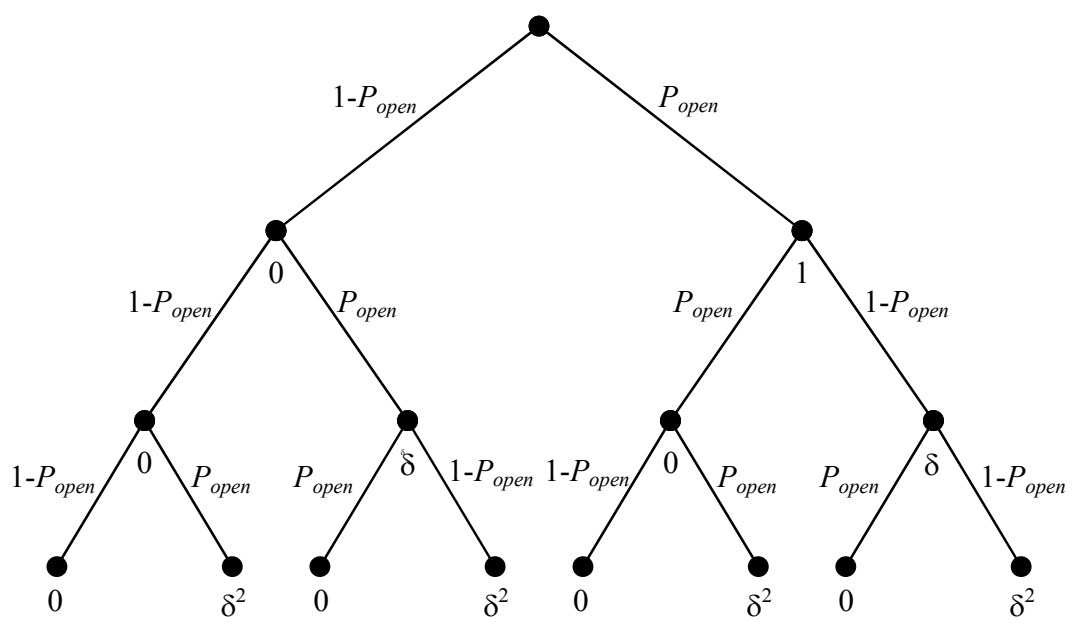

Several items of interest can be seen in the figure. First, note that for $P_{\text {inc }} \leq 0.5$, any constituent who believes that their party can probably win an open-seat election $\left(P_{\text {open }} \geq 0.5\right)$ will favor term limits. That is, for many reasonable and plausible values of $P_{\text {inc }}$ and $P_{\text {open }}$, the constituent will favor term limits irrespective of his or her time horizon. Second, for others strategic support for term limits depends on the constituent's time horizon, as we might expect. For constituents who believe that $P_{\text {open }}<0.5$, as they weight the future more heavily with a $\delta$ closer to one, more of the possible mixes of $P_{i n c}$ and $P_{\text {open }}$ lead to support for an unlimited-term regime. Likewise, the more the constituent weights the immediate possibility of gains under term limits, the more likely he or she will support term limits.

Empirically, the primary result of the model simply shows that the strategic concerns can exist, and would often lead to support for term limits. Indeed, within the reasonable range of $P_{\text {inc }}$ out-party constituents would only support the current regime if they believed that their party would have a difficult time winning even an open seat election.

\section{Theory 2: Responsiveness to Strategic Concerns}

Not all out-partisans, however, should be equally responsive to these district-level strategic effects. In addition to these district-level concerns, two broader concerns might lead at least some constituents to ignore the strategic concerns in their own district. 
Figure 3. Determinants of Strategic Support for Term Limits

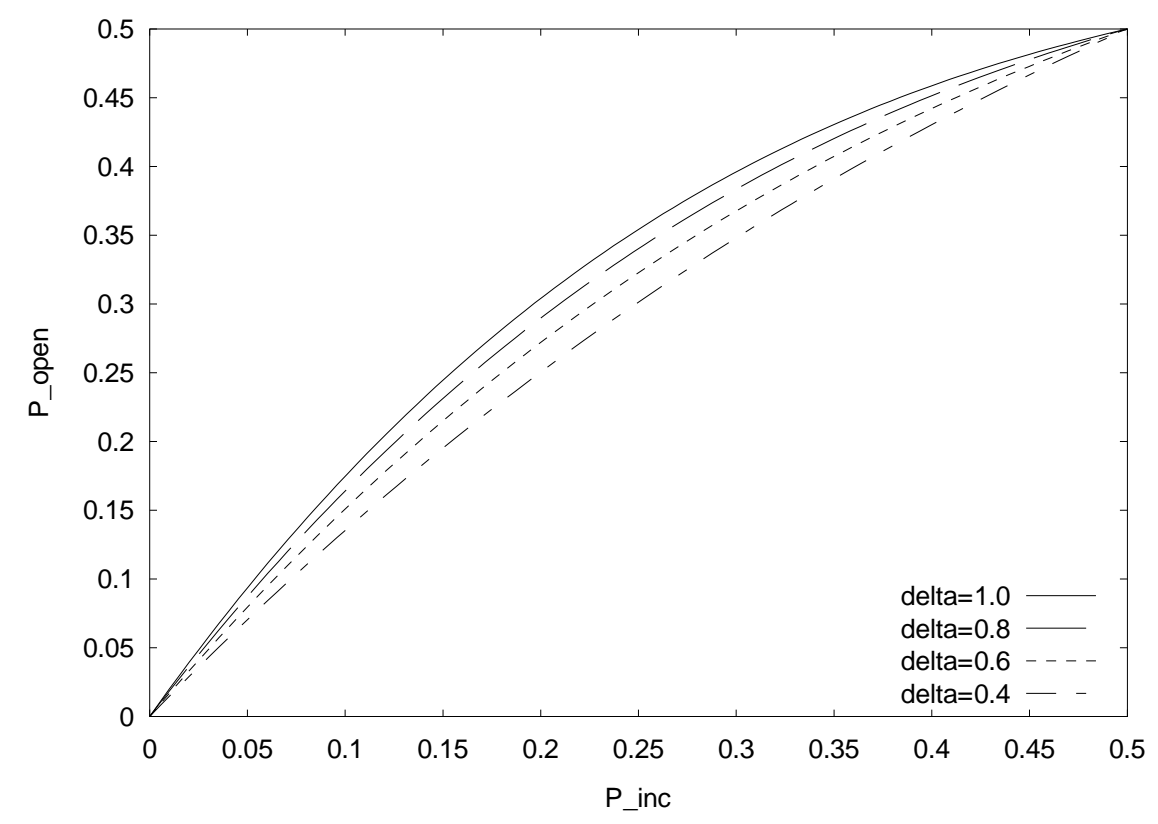

First, there may be broader party effects. Almost all of the models of partisan effects of term limits on the U.S. House predict the Republicans gaining seats under term limits. One simple reason for this prediction is that most of the models were constructed (if not published) before the Republicans gained control of Congress in 1995. Reed and Schansberg (1996) argue that term limits for the U.S. House would reduce the Democratic advantage from approximately 100 to 60 seats, in large part because it would force the post-Watergate classes of Representatives out of Congress and their districts into open-seat elections (Reed and Schansberg 1996, 137). Using a dynamic model, Gilmour and Rothstein (1996) find that term limits will increase a party's representation if its incumbents perform worse electorally than those of the other party while its "new faces" perform better. This condition also implies that the party would be in the minority without term limits and the majority with them. Even if the pieces in question were incorrect or overly dependent on the House being held by the Democrats at the time, these arguments still serve to show that elite discourse in this time period generally considered term limits for Congress to favor Republicans. Empirically, this predicts that Democrats should be less sensitive to district-level strategic concerns, since they are cross-pressured, while Republicans should have their district-level strategic effect amplified. 
Second, term limits may have a conservatizing effect on legislatures. Note that this effect does not depend on the historical happenstance that Republicans were in the minority when most of these models were being built. Will (1992) and others argue that term limits would alter the balance of costs and benefits of legislative service. Will argues that the possibility of unlimited terms attracts legislative candidates with a more activist mindset, who would be more likely to expand governmental interference in the economy. He writes that term limits would make legislative service less attractive to these people and more attractive to conservatives, and so reduce the role of the federal and state governments to a level that Will finds more acceptable. This makes some sense from an academic point of view as well. The original pieces arguing for legislative professionalization in the 1970s (Citizen's Conference on State Legislatures 1971; Burns 1971) argued that legislatures should change in order to become more attractive to younger, more policy-minded people, and indeed the changes they made seem to have had the predicted effect. It makes sense, then, for those opposed to legislative professionalization to advocate changes which would serve as disincentives to legislative service from the same type of activist, policy-minded legislators. Overall, Will claims that term limits would have the effect of making government generally more conservative and laissez-faire. To the extent that the liberal/conservative, activist/laissez-faire dimension Will uses correlates with party, this should lead to weakened support for congressional term limits among Democrats and stronger support among Republicans.

Taken together, these factors create an additional pressure for or against supporting term limits. Both of these factors imply higher support for term limits among Republicans, who might find themselves advantaged under term limits. Democrats in the local out-party might find themselves crosspressured, desiring term limits because it would help them to elect a Representative more to their liking, but disfavoring them because it might lead to fewer Democrats being elected to the House in aggregate. That is, their local partisan concerns and their national partisan concerns could be in opposition to each other. For Republicans, on the other hand, both the local- and national-level strategic concerns reinforce each other.

The empirical question is who might find these second-level concerns most compelling. Since both involve more aggregate and abstracted matters, it makes sense to believe that stronger partisans should pay more attention to the second-level concerns. We should expect stronger partisans to take a greater interest in the national welfare of their party than do weaker partisans. This leads to the empirical prediction that among Democrats, weak Democrats should be more supportive of term limits than strong Democrats, and that among Republicans support should be high among strong Republicans, though still strong even among weak Republicans. Further, the second- 
level theories show that even after gaining control of both House and Senate, Republican voters might still have a strategic reason to support term limits for Congress.

Overall, the simple formal model of term limits support and these second-level theoretical concerns make two empirical predictions. First, outpartisans should be more supportive of term limits than are in-partisans. Second, this effect should be stronger among weak Democrats than strong Democrats, and stronger among strong Republicans than weak. It is often noted that partisan "leaners" can sometimes appear to be stronger partisans than those that self-identify as weak partisans, perhaps because they are independents who are reporting their voting intentions (Keith et al. 1992). Because the relationship between these two levels of partisanship is not clear, I do not make any predictions between them.

\section{Data and Methods}

To see whether these relationships actually occur, I use the 1992, 1994, and 1998 National Election Studies as bound together within the 1948-2002 cumulative dataset (Sapiro, Rosenstone, et al. 2002). These were the only three years in which the NES asked respondents whether they favored or opposed a 12-year limit on congressional service. In all three years, the question asked was, "A law has been proposed that would limit members of Congress to no more than 12 consecutive years of service in that office. Do you favor or oppose such a law?"

The main set of independent variables is party (measured using the standard 7-point party identification variable) and in- or out-party status. I measure the in- or out-party status of a respondent with the "Type of House race" variable, counting out-partisans as those whose incumbents are of the other party or in whose race there was an unopposed candidate of the other party. Everyone else is lumped together into an in-partisan / indeterminate group. I also ran the models using a tripartite strict-in-party / indeterminate / out-party distinction, but the results were not substantively different. The standard approach would be to simply interact party identification and outpartisan status. However, this places linearity restrictions on the model-it requires the difference between strong and weak Democrats to be the same as the difference between strong and weak Republicans. With such a large dataset, there is little reason to conserve degrees of freedom, so I simply break down the respondents into thirteen exhaustive and mutually exclusive categories. I have categories for (nonstrict) in- and out-partisans for each level of party ID, and an omitted category of nonpartisans and apoliticals. After running the model, it is then simple to compare coefficients on in- and out-partisans to see whether out-partisans are significantly more likely to 
prefer term limits for each level of party ID. For this, I use simple Wald tests.

In addition, I include several variables as controls for factors found significant in other studies. Age, race, and sex are coded directly from the appropriate variables, with race taking on an Anglo / non-Anglo distinction. Similarly, I include the standard liberal-conservative ideology score, with positive values denoting conservatism. I also include a cynicism scale built from the standard four variables, with higher numbers denoting increasing cynicism. Finally, I include dummies for the 1994 and 1998 elections. In a second version of the model, I add variables for dissatisfaction with the performance of the incumbent and of Congress. These are pushed to a second run of the model because their inclusion drops large numbers of respondents. I regress both models using logit.

\section{Results}

The empirical results support both hypotheses. Table 1 provides the results of the first statistical model. The upper section of the table is the standard display of coefficients and summary statistics. The lower section of the table reports the results of hypothesis tests. Each hypothesis test is against the null that the coefficients of in- and out-partisans are equal, and all are two-sided. The "hypothesis test" column indicates which level of party identification is being tested, the "out-in" column reports the value of the out-party coefficient minus the in-party coefficient, the "SE" column reports the standard error of this difference, and the $p>z$ column gives the results of a one-sided test. I generate standard errors for the differences between out- and in-partisans directly from the variance-covariance matrix.

For all levels of party identification, out-partisans are more likely to support term limits than are in-partisans. In four out of the six levels, outpartisans are more likely to support term limits at a significance level of 0.10 or better. Further, the pattern predicted by the second-level theories holds. The absolute differences between in- and out-partisans are larger for weak Democrats and Democratic leaners than for strong Democrats, and the difference for strong Republicans is much larger than for weak Republicans or Republican leaners. As might be expected, this translates into clear statistical significance for weak Democrats, Democratic leaners, and strong Republicans, weaker significance for strong Democrats, and a lack of significance for all other levels of party identification.

The control variables perform about as expected from previous models, with the possible exception of race. The Anglo variable, which other models might predict should be negative, is clearly not a significant predictor. While the logit model reports more significant control variables than other models 
Table 1. Determinants of Term Limits Support

\begin{tabular}{|c|c|c|c|}
\hline Variable & Coefficient & SE & $p>|z|$ \\
\hline Constant & 0.649 & 0.242 & 0.007 \\
\hline 1994 & -0.287 & 0.098 & 0.004 \\
\hline 1998 & -0.467 & 0.106 & 0.000 \\
\hline Age & 0.007 & 0.003 & 0.005 \\
\hline Female & 0.279 & 0.083 & 0.001 \\
\hline Anglo & 0.008 & 0.103 & 0.937 \\
\hline Cynicism & 0.134 & 0.019 & 0.000 \\
\hline Ideology & 0.076 & 0.034 & 0.024 \\
\hline Strong D, in & -0.697 & 0.180 & 0.000 \\
\hline Strong D, out & -0.417 & 0.226 & 0.064 \\
\hline Weak $\mathrm{D}$, in & -0.430 & 0.182 & 0.018 \\
\hline Weak D, out & -0.043 & 0.218 & 0.845 \\
\hline D Leaner, in & -0.231 & 0.195 & 0.235 \\
\hline D Leaner, out & 0.268 & 0.247 & 0.279 \\
\hline R Leaner, in & 0.126 & 0.219 & 0.564 \\
\hline $\mathrm{R}$ leaner, out & 0.281 & 0.250 & 0.262 \\
\hline Weak $R$, in & 0.016 & 0.197 & 0.937 \\
\hline Weak R, out & 0.117 & 0.227 & 0.607 \\
\hline Strong $R$, in & -0.098 & 0.202 & 0.628 \\
\hline Strong R, out & 0.512 & 0.261 & 0.049 \\
\hline LR $\chi^{2}$ & 180.9 & $p>\chi^{2}$ & 0.000 \\
\hline Hypothesis Test & Out-in & SE & $p>z$ \\
\hline Strong D & 0.280 & 0.201 & 0.082 \\
\hline Weak D & 0.387 & 0.202 & 0.027 \\
\hline D Leaner & 0.499 & 0.242 & 0.020 \\
\hline R Leaner & 0.155 & 0.265 & 0.279 \\
\hline Weak R & 0.101 & 0.223 & 0.325 \\
\hline Strong R & 0.610 & 0.255 & 0.008 \\
\hline
\end{tabular}

used elsewhere, this is in some part due to the much larger $N$ here. Overall, the model does not perform much better than a naive model, but this is primarily due to the lopsided nature of the dependent variable. With nearly 80 percent of respondents supporting term limits, a naive model that predicts that everyone will support term limits will do well. The model predicts 78.7 percent of responses correctly, but only 28 out of 3756 responses are predicted to be "No," and half of those are false. I also ran this model with skewed logit or "scobit," but the results did not differ appreciably and the model generated equally skewed results (Nagler 1994). 
Table 2. Determinants of Term Limits Support, Modified Model

\begin{tabular}{lccc}
\hline Variable & Coefficient & SE & $p>|z|$ \\
\hline Constant & 0.822 & 0.336 & 0.015 \\
1994 & -0.217 & 0.125 & 0.083 \\
1998 & -0.393 & 0.137 & 0.004 \\
Age & 0.006 & 0.003 & 0.087 \\
Female & 0.245 & 0.105 & 0.019 \\
Anglo & -0.095 & 0.135 & 0.484 \\
Cynicism & 0.130 & 0.025 & 0.000 \\
Ideology & 0.090 & 0.043 & 0.036 \\
Disapp. MC & 0.222 & 0.152 & 0.143 \\
Disapp. Cong. & -0.154 & 0.116 & 0.182 \\
Strong D, in & -0.871 & 0.248 & 0.000 \\
Strong D, out & -0.581 & 0.285 & 0.042 \\
Weak D, in & -0.477 & 0.255 & 0.061 \\
Weak D, out & -0.024 & 0.292 & 0.935 \\
D Leaner, in & -0.473 & 0.268 & 0.078 \\
D Leaner, out & 0.109 & 0.319 & 0.732 \\
R Leaner, in & 0.209 & 0.304 & 0.491 \\
R leaner, out & 0.076 & 0.313 & 0.807 \\
Weak R, in & -0.225 & 0.278 & 0.419 \\
Weak R, out & -0.060 & 0.288 & 0.836 \\
Strong R, in & -0.115 & 0.272 & 0.672 \\
Strong R, out & 0.478 & 0.337 & 0.156 \\
LR $\chi^{2}$ & 122.4 & $p>\chi^{2}$ & 0.000 \\
\hline Hypothesis Test & Out-in & SE & 0.107 \\
\hline Strong D & 0.290 & 0.234 & 0.026 \\
Weak D & 0.453 & 0.258 & 0.657 \\
D Leaner & 0.582 & 0.299 & 0.031 \\
R Leaner & 0.133 & 0.277 & \\
Weak R & 0.593 & 0.317 & \\
Strong R & & & \\
\hline & & & \\
\hline & & & \\
\hline & & & \\
\hline
\end{tabular}

Table 2 displays the results for the second model, which includes variables for disapproval of Congress and of the respondent's incumbent. Neither of these variables are significant at a 0.10 level, and one is in the wrong direction. This model does not otherwise differ strongly from the previous one. The only variables that move into or out of 0.10 -level significance are "D Leaner, in," which becomes significant, and "Strong R, out," which becomes insignificant. However, the party variables are of little interest on their own in any case. What matters is how they compare to each 


\section{2 | James Coleman Battista}

other. The hypothesis tests are effectively identical. Results significant at a 0.05 level in the unmodified model remain so in this model. The test $p$ for strong Democrats increases only from 0.082 to 0.107 , which happens to drive it over a standard threshold value instead of just squeaking under, but the actual difference is tiny. For weak and leaner Republicans, the modified model repeats the null finding of the previous model. Thus, the results are robust to the inclusion of variables with no clear effect. Overall, the model performs similarly to the unmodified, correctly predicting 77.2 percent of responses, but with only a bare handful of predicted "No's."

Table 3 reports the first differences for out- versus in-party status for each level of party identification. To compute these, I set all other variables at their mean for that level of party identification - that is, the baseline probability is computed separately for each level. The number reported is the change in the probability of favoring term limits resulting from shifting a respondent from the in-party to the out-party. The results again confirm the effects of the party identification on sensitivity to district-level strategic concerns, with the first difference for weak Democrats stronger than for strong, and the first difference for strong Republicans much greater than that for weak. The first differences are not large in an absolute sense, lying between five and ten percentage points for those levels of party identification where the effect is significant. However, it should be noted that the high baseline probabilities of favoring term limits limits the actual effect any variable could have.

\section{Discussion and Conclusions}

My findings here both support and challenge existing work. Using a subset of the data I use, Stein, Johnson, and Post found that partisan incongruence with their Representative correlates with higher probabilities of supporting term limits, at least among more attentive respondents, but the relationship they find is only significant at the 0.10 level. ${ }^{2}$ My findings support

Table 3. First Differences of Out-Partisan Status

\begin{tabular}{lcc}
\hline Party ID & Original Model & Modified Model \\
\hline Strong D & 0.057 & 0.058 \\
Weak D & 0.067 & 0.070 \\
D Leaner & 0.076 & 0.079 \\
R Leaner & 0.019 & 0.020 \\
Weak R & 0.014 & 0.015 \\
Strong R & 0.074 & 0.077 \\
\hline
\end{tabular}


the idea that being represented by a party not your own leads to more support for term limits, and breaking this down into different effects for each level of party identification exposes one reason for the weak effect they find. ${ }^{3}$ If some partisans respond to district-level strategic effects and others do not, we should expect to see at most only a weak effect that combines the mix of strong and null effects I find.

The results for the control variables tend to challenge most current models. Both Karp (1995) and Stein, Johnson, and Post (2002) found that women were no more likely to support term limits than men, even though term limits were widely predicted to increase representation of women in Congress. Here, though, I find that women are significantly more likely to support term limits than are men. Likewise, Karp (1995), Donovan and Snipp (1994), and Stein, Johnson, and Post all find that while the coefficient on ideology is in the correct direction, it is not significant. Here, I find the same effect is significant at a 0.05 level. Stein, Johnson, and Post (2002) report that cynicism is insignificant, reversing Karp's (1995) finding, but that the coefficient becomes significant if out-partisan status is dropped from the model. They interpret this to mean that "trust of each level of government is overshadowed by partisan incongruence with elected representatives" (Stein, Johnson, and Post 2002, 475). However, I find with a larger $N$ and with the effects of partisan incongruence broken down over different levels of party identification that cynicism has a very strong positive effect on support for term limits, as Karp had found.

In sum, I find that representation by another party is linked to support for term limits, supporting the idea that some support for term limits is caused by strategizing, or by a psychological process mimicking the effects of strategizing. Further, I find that sensitivity to partisan incongruence is stronger among weak Democrats and strong Republicans. This supports the idea that stronger Democrats have a direct opposition to term limits, based perhaps on the Republican-favoring and conservatizing effects term limits were predicted to have.

One area this might have some effects over the future is in areas with large numbers of immigrants or descendants of recent immigrants, especially Latinos in the South and Southwest. We might expect Latinos and other minority populations to generally favor term limits, as term limits allow more frequent access to open-seat elections and might be expected to result in increased representation of the relevant minority group (though studies have not found a clear and consistent effect of minority or under-represented status). This is especially true of term limits operating at the local level. Here, the secondary layer of national partisan (or group-based) concerns simply vanishes - getting a Latino elected to city council in one city in an 


\section{4 | James Coleman Battista}

election thrown open due to term limits has no causal relationship whatsoever to another race for city council in another city in another state. If anything, we might expect out-groups to favor term limits more strongly in such a setting, because having politicians of your group elected to local office, taking part in party work, being visible to party members higher up in the state party, and possibly moving up the political opportunity structure would most likely increase (or at least certainly not diminish) the probability of another member of that out-group being elected in the future as it makes it clear that they can be an important part of electoral coalitions. How this interacts with partisan concerns is hard to predict, and will probably depend on which parties recruit a given group into their broad coalition. For example, consider Latinos in the Southwest, who tend to vote Democratically, if not monolithically so. These voters might strongly favor term limits on ethnic lines if they see term limits at the local level helping Latino politicians take office in city councils, county commissions, and school boards. If the Democratic party successfully and firmly integrates Latinos into its coalition as it previously did northern ethnic Catholics and Black voters, we might expect Latinos to become particularly cross-pressured over time if it seems that term limits gives Latinos more representation, but in a legislature that is more conservative and arguably less likely to pass pro-Latino legislation. However, if Latino voters are integrated into the Democratic coalition less firmly and see voting Republican as more of a real option, we should expect support and pressure for term limits at the state and local levels to increase as the numbers of Latino voters in the Southwest increase.

The formal and statistical models in this paper are not intended to be a fully explanatory model of support for term limits. My goal was merely to test the predictions of one partial model. However, my findings and the findings of others point to significant problems with general explanations of term limits. All of the models, including the models in this paper, do not explain the single most important and interesting finding: that term limits could erupt onto the public stage with the support of nearly 80 percent of those surveyed. All of the models begin with a very large constant term, often large enough to effectively predict that everyone, minus at most an absolute handful of respondents, will support term limits. Clearly, this represents a deficiency in our models. With more work, theoretical and empirical modelers should be able to drag probability mass out of the constant term and into the effects of actual explanatory variables.

\section{NOTES}

${ }^{1}$ This should be especially true of a challenger with the wherewithal to defeat an incumbent. 
${ }^{2}$ I drop their attentiveness variable to avoid inferential difficulties with three-way interacted variables and to make the hypothesis testing clearer. Earlier models, not reported here, indicated that their attentiveness variable was not significant on its own.

${ }^{3}$ In their NES sample, their Houston survey results are much sharper.

\section{REFERENCES}

Boeckelman, Keith, and Gina Corell. 1996. An Analysis of Term Limitation Elections. In Legislative Term Limits: Public Choice Perspectives, ed. Bernard Grofman. Boston: Kluwer.

Burns, John. 1971. The Sometime Governments. New York: Bantam.

Carey, John M., Richard G. Niemi, and Lynda W. Powell. 1998. The Effects of Term Limits on State Legislatures. Legislative Studies Quarterly 23:271-300.

Carey, John M., Richard G. Niemi, and Lynda W. Powell. 2000. Term Limits in the State Legislatures. Ann Arbor: University of Michigan Press.

Citizen's Conference on State Legislatures. 1971. State Legislatures: An Evaluation of Their Effectiveness. New York: Praeger.

Donovan, Todd, and Joseph R. Snipp. 1994. Support for Legislative Term Limitations in California: Group Representation, Partisanship, and Campaign Information. Journal of Politics 56:492-501.

Gilmour, John B., and Paul Rothstein. 1996. Term Limitation in a Dynamic Model of Partisan Balance. In Legislative Term Limits: Public Choice Perspectives, ed. Bernard Grofman. Norwell, MA: Kluwer.

Grofman, Bernard. 1996. Legislative Term Limits: Public Choice Perspectives. Boston: Kluwer.

Karp, Jeffrey A. 1995. Explaining Public Support for Legislative Term Limits. Public Opinion Quarterly 59:373-391.

Keith, Bruce E., David Magleby, Candice J. Nelson, Elizabeth A. Orr, Mark C. Westlye, and Raymond E. Wolfinger. 1992. The Myth of the Independent Voter. Berkeley: University of California.

Moncrief, Gary F., Joel A. Thompson, Michael Haddon, and Robert Hoyer. 1996. For Whom the Bell Tolls: Term Limits and State Legislatures. In Legislative Term Limits: Public Choice Perspectives, ed. Bernard Grofman. Boston: Kluwer.

Nagler, Jonathan. 1994. Scobit: An Alternative Estimator to Logit and Probit. American Journal of Political Science 38:230-255.

Rausch, Jr., John David, and Gary W. Copeland. 1996. Term Limits in Oklahoma, California, and Colorado in 1990. In Legislative Term Limits: Public Choice Perspectives, ed. Bernard Grofman. Boston: Kluwer.

Reed, W. Robert, and D. Eric Schansberg. 1996. An Analysis of the Impact of Congressional Term Limits on Turnover and Party Balance. In Legislative Term Limits: Public Choice Perspectives, ed. Bernard Grofman. Norwell, MA: Kluwer.

Sapiro, Virginia, Steven J. Rosenstone, and the National Election Studies. 2002. "19482002 Cumulative Data File [dataset].” Ann Arbor: University of Michigan, Center for Political Studies [producer and distributor].

Stein, Robert M., Martin Johnson, and Stephanie Shirley Post. 2002. Public Support for Term Limits: Another Look at Conventional Thinking. Legislative Studies Quarterly 27:459-480. 


\section{6 | James Coleman Battista}

Thompson, Joel A., and Gary F. Moncrief. 1993. The Implications of Term Limits for Women and Minorities: Some Evidence from the States. Social Science Quarterly 74:300-309.

Will, George F. 1992. Restoration: Congress, Term Limits, and the Recovery of Deliberative Democracy. New York: Free Press. 